THE DETERMINATION OF FACTORS RELATED TO ACADEMIC ACHIEVEMENT IN THE UNIVERSITY: IMPLICATIONS FOR THE SELECTION AND COUNSELLING OF STUDENTS

\title{
JAVIER TOURON
}

Instituto de Ciencias de la Educación, Universidad de Navarra, Pamplona, Spain

\section{ABSTRACT}

An initial diagnosis of some educational and psychological capacities of students on arrival at university were studied. This enabled us to find out what factors had a greater influence on academic achievement at the end of the first year. $U$ sing the techniques of multiple regression we established the optimal achievement performances expected from each of the students. Secondary school marks, the academic achievement tests and the intermediate examinations at university were the best set of predictors of academic performance. Differential aptitudes of intelligence increase considerably the accuracy of the prediction. Values of $R$ of between 0.71 to 0.88 were reached depending on the criteria used. The usefulness of the prediction equations as a tool for increasing personalized attention to students is pointed out and a case made for the establishment of objective mechanisms for admission to higher education.

Introduction

In recent years, a number of anomalous situations have arisen in university life in Spain such as the large number of students who do not pass their exams, the wastage rate and the continuous complaints of the teaching staff who maintain that the students reach the university with a very poor preparation as regards the knowledge and intellectual habits necessary for attaining reasonable results at the end of their first year studies.

For these reasons we have centred our attention, since 1980, on research related to the real situation of the students on arrival at the university, using a series of instruments which allowed objective measurement. This initial diagno-sis allowed us to assess the potential capacity of the students from the beginning of the academic year. The capacities and characteristics studied allowed us to find out what factors had a greater influence on academic achievement at the end of the first year. Using the techniques of multiple regression we established the optimal achievement expected from each of the students.

In 1971 and 1972 a study had been carried out in our university about the deficiencies of first year students in the different centres as regards the level of maturity, degree of intellectual formation, aspects related to personal relations, etc. (Gonzalez-Simancas, 1973). This study was designed to give teachers and academic authorities, objective information that could encourage the establishment of a counselling activity based on the knowledge of what was really happening. It was understood that the counselling activity was inherent to the job of teaching and that it was not therefore a question of specialised staff.

In our research project we studied the problem of knowing more about the students at the time of their arrival at the university in the Facultad de Ciencias Biológicas with the aim of 
indicating what could be expected from each student. In recent years various researchers have studied the question of determining factors especially as related to the prediction of academic achievement (Bloom, 1980; Escudero, 1981; Dumont and Troelstrup, 1981; Murphy, 1981, O'Brien and Ginsburg, 1980; Muraki and Whaley, 1980 amongst others). Also interest has been centred on discovering the most adequate and just admission mecha-nisms (Feletti and Fisher, 1979; Ferrier and Gauldie, 1979; Cid Palacios, 1977). In this university in 1980, a study was carried out in the School of Medicine with the aim of establishing a relationship between the admission exam results and the achievement of the students later on (Aguirre, 1980). We have extended this analysis to include a large number of educational and psychological factors as we considered that, by finding the best predictors for academic achievement, we would be better able to offer a solid basis for improving selection and counselling mechanisms.

The initial diagnosis included the following aspects:

(a) secondary school results;

(b) knowledge and intellectual capacities in relation to the main subjects studied in the first year university course: mathematics, physics, chem-istry, biology;

(c) reading capacity: speed and understanding;

(d) habits and opinions about study methods;

(e) general intelligence ("g" factor);

(f) differential intelligence aptitudes ("s" factors);

(g) basic personality factors;

(h) vocational and professional preferences;

(i) academic achievement in the first year at university.

To be able to establish equations of multiple regression, the predictive study was based on the correlations of the characteristics evaluated in the initial diagnosis with the academic achievement at the end of the year. Our study was then, a longitudinal, evaluative description related to the answers we were looking for. It was centred on the real situation of the students on entering the university and a trend study was carried out based on a longitudinal consideration of the initial description (Best, 1974).

\section{Material and Methods}

\section{(a) MATERIAL}

We used the academic records of the students where their marks could be found and other relevant information such as age, sex, socio-economic status, and residence. The academic achievement tests were developed in this university by teachers of first year courses. There 
were four, fifty item, multiple choice, tests with a reliability of between 0.82 and 0.68 (KR20) with a standard deviation of between 6.69 and 4.49 points. The content of the tests referred to the subjects previously mentioned and were intended to explore the levels of knowledge, understanding and application as described by Bloom et al., (1971) in each subject. The reading capacity test developed for this project measured speed in words per minute and also the degree of understanding and retention, expressed in percentages. The product of both factors divided by 100 determined and indicator of reading capacity (Ubieto, 1981; Zielke, 1973).

Study habits and opinions were studied through the questionnaire DPE-48 by Castillo (1978).

General intelligence was measured by the test Dominos, D-48 by Anstey which has a high saturation of "g" factor (0.86) which is superior even to that of Raven's progressive matrix, (0.76). The battery DAT (Differential Aptitude Test) by Bennett, Seashore, and Wesman, was used to measure verbal reasoning (V R), numerical aptitude (NA), abstract reasoning (AR), and spatial relations (SR). This battery is one of the most used for selection and counselling (Cronb $\neg$ ach, 1954, 1970; Thorndike, 1965; Thorndike and Hagen, 1978; Adams, 1970).

The basic characteristics of personality were studied through the S ixteen Personality Factors (16PF) by Cattell et al., (1979), Seisdedos (1978).

Vocational and Professional Interests were measured through the Kuder Preference Record, Vocational, Form C (Seisdedos, 1978). Lastly a study of the academic results throughout the year was made using the marks given by the appropriate teachers.

\section{(b) METHODS}

First, a descriptive study of each variable was carried out calculating distribution, mean, standard deviation, standard error of the mean, and also the goodness of fit to the normal distribution with the Pearson Chi-square test. Once this study had been finished the scores were transformed into a scaled score $(T=10 Z+50)$ (Noll, and Scannell, 1972; Seashore, 1968). The transformation was made linearly in the cases in which the normality hypothesis was accepted. Therefore the original form of the distributions was unchanged (Ferguson, 1976: Angoff, 1971). In the other cases the variables were transformed to the normal form (Adams, 1970). In this way we were able to know the form of distribution for each variable and accept the basic assumptions of later statistical analysis.

The data was processed with the Programme Interest II, developed by Schneider in the University of Uppsala and supplied by IBM. It was used in an IBM 4331 system in the Data Processing Center in our university. The major part of the analysis, such as the analysis of variance, will not be considered on this occasion for reasons of space. We will mention only the results based on the correlations of the different variables with the criterion to be predicted and the prediction equations. As our variables were expressed in a scale of intervals we calculated the coefficient of correlation product-moment of Bravais-Pearson. For the calculation of the prediction equations - that is multiple regression equations - we prepared a programme in PL-1 language based on the method of selection of variables Wherry-Dolittle 
(Garret, 1966). This is an analytical procedure which permits the selection of the best set of predictors (i.e., the set that produces a maximum multiple-R (Touron, 1982 in press). The programme starts operating on the correlation matrix of the different variables with the criterion to be predicted or dependent variables (the final marks in mathematics, physics, chemistry and biology), selecting those that, as a set, explain the largest proportion of the variance.

Criterion and predictors are linked through an equation of this kind:

$Y=a X 1 b X 2+\ldots+n X n+K$; where $a, b$, and $n$ are the regression coefficients; $X 1, X 2 \ldots X n$, the predictors, and $\mathrm{K}$ a constant (Guilford, 1965).

Results

We will only mention those variables that have a significant correlation with the academic achievement at the end of the first year (i.e., the criterion to be predicted). These results are included in Tables I and II.

\section{TABLE I}

Variables that Present a Significant Correlation with University Academic Achievement at the End of the First Year (June)

\begin{tabular}{|l|l|l|l|l|}
\hline Variables & Criterion & & & \\
\hline & Mathematics & Physics & Chemistry & Biology \\
\hline Mathematics - SC & 0.6509 & 0.5298 & 0.5709 & 0.5788 \\
\hline Physics - SC & 0.5739 & 0.4548 & 0.5919 & 0.5209 \\
\hline Chemistry - SC & 0.5522 & 0.4223 & 0.5058 & 0.5204 \\
\hline Biology - SC & 0.5454 & 0.4193 & 0.4684 & 0.5091 \\
\hline Average - SC & 0.5953 & 0.5086 & 05618 & 0.6079 \\
\hline State entrance exam & 0.4901 & 0.4915 & 0.4930 & 0.4988 \\
\hline TAA-Mathematics & 0.5680 & 0.5224 & 0.5060 & 0.3950 \\
\hline TAA - Physics & 0.3512 & - & 0.2624 & 0.2045 \\
\hline TAA - Chemistry & 0.4598 & 0.5789 & 0.4832 & 0.4751 \\
\hline TAA-Biology & 0.4612 & 0.4585 & 0.4073 & 0.5652 \\
\hline $\begin{array}{l}\text { Reading } \\
\text { understanding }\end{array}$ & 0.2201 & 0.3157 & 0.2551 & 0.3748 \\
\hline Reading capacity & - & 0.2582 & 0.2945 & - \\
\hline General Intelligence & 0.2583 & 0.3752 & 0.3827 & 0.2239 \\
\hline Verbal reasoning & - & 0.4615 & 0.2390 & 0.2997 \\
\hline
\end{tabular} $\begin{aligned} & \text { SC = Secondary School } \\
& \text { TAA = Test of academic achievement }\end{aligned}$

The variables that have the highest correlation are those that refer to previous academic achievement i.e., S.C.-Marks $(0.65-0.42)$. There is a moderate correlation with those variables which refer to the test of academic achievement taken on arrival at the university (0.58-0.41). 
These values are similar to those found in some other studies (Froemel and Leyton, 1980) although in some cases values of 0.80 have been reached.

The correlations of the variables which have to do with intermediate exams are between 0.82 and 0.58 . This seems to be logical as the characteristics of future achievement are far more defined by these intermediate exams than by those taken by the students in secondary education. In other words the predictive value of these second kind of results is much higher. Other authors in Spain (Escudero, 1981) have found values from 0.52 to 0.48 relating the marks in secondary education to achievement at the end of the first year at university. We should also underline in this group of variables that the results of the State admission examination for the universities in Spain ("Selectividad") have far less predictive value than the previous school results. This result was contrasted with other findings (Escudero, 1981) where the same results were found. We have also traced the results since 1971 for students who studied the same subjects and we rid a correlation of 0.32 in relation to the results at the end of the first year (Touron, unpublished data).

\section{TABLE II}

Variables that Present a Significant Correlation with University Academic Achievement at the End of the First Year (June)

\begin{tabular}{|c|c|c|c|c|}
\hline \multirow[t]{2}{*}{ Variables } & \multicolumn{4}{|l|}{ Criterion } \\
\hline & Mathematics & Physics & Chemistry & Biology \\
\hline $\begin{array}{l}\text { Numerical aptitude } \\
\text { DAT-NA }\end{array}$ & 0.4012 & 0.3433 & 0.3613 & 0.2259 \\
\hline $\begin{array}{l}\text { Spatial relations DAT- } \\
\text { SR }\end{array}$ & - & 0.3576 & - & - \\
\hline DAT-VR+NA & 0.3072 & 0.4840 & 0.3581 & 0.3184 \\
\hline A-Factor (16PF) & - & - & - & 0.2271 \\
\hline C-Factor (16PF) & 0.2108 & - & - & - \\
\hline E-Factor (16PF) & 0.2558 & 0.2301 & 0.2908 & 0.2703 \\
\hline $\begin{array}{l}\text { Ql-Factor } \\
\text { anxiety }\end{array}$ & -0.2180 & - & - & - \\
\hline QIII-Factor (16PF) & -0.2196 & - & - & - \\
\hline Calculation & 0.2345 & - & - & - \\
\hline Scientific & 0.2250 & - & - & - \\
\hline Maths. Int. Exam. & $\underline{0.8220}$ & 0.5834 & 0.6325 & 0.6064 \\
\hline Physics Int. Exam & 0.6779 & $\underline{0.7684}$ & 0.6845 & 0.6020 \\
\hline Chemistry Int. Ex. & 0.6678 & 0.6695 & $\underline{0.7418}$ & 0.6637 \\
\hline Biology Int. Exam. & 0.6206 & 0.6250 & 0.6509 & $\underline{0.7763}$ \\
\hline № Variables & 24 & 21 & 21 & 21 \\
\hline
\end{tabular}


The second group of variables that have a significant correlation with the criterion are those related to general intelligence and differential aptitudes. These correlations are relatively low and are clearly less important than those referring to previous academic achievement. The highest correlation in the intelligence test was 0.38 and the lowest 0.22 . The differential aptitudes of intelligence have correlations of between 0.46 and 0.24 .

Other variables which have a direct relation to academic achievement are those which measure some aspects of personality. The results seem to indicate that self assurance favours academic achievement as we find correlations of between 0.29 and 0.23 . Muraki and Whaley (1980) describe values of 0.26 although in other studies cited by them values of 0.42 have been discovered. Vocational interests ("calculation" and "scientific") have a correlation of 0.23 with mathematics. Muraki and Whaley cite correlations of 0.28 between attitudes towards mathematics and achievement in this subject.

TABLE III

Variables that are Included in the Prediction Equations for Academic Achievement in Each Subject

\begin{tabular}{|c|c|c|c|c|}
\hline Variables & Criterion & & & \\
\hline & Mathematics & Physics & Chemistry & Biology \\
\hline X Maths. S.C. & 1모 & 2a & (5a) & $4 \underline{a}$ \\
\hline X Physics S.C. & & 1aㅗ & 1aㅡ & \\
\hline X Chemistry S.C. & & & $\left(8^{a}\right)$ & \\
\hline \multicolumn{5}{|l|}{ X Biology S.C. } \\
\hline X Average S.C. & & & & 1aㅡ \\
\hline $\begin{array}{l}\mathrm{X} \text { State entrance } \\
\text { exam }\end{array}$ & & $\left(8^{a}\right)$ & (9a) & \\
\hline TAA - Maths. & 2a & $4 \underline{a}$ & 2a & (7aㅡ) \\
\hline TAA - Physics & & & & 6a \\
\hline \multicolumn{5}{|l|}{ TAA - Chemistry } \\
\hline TAA - Biology & 3aㅗ & (6모 & 3a & $2 \underline{a}$ \\
\hline $\begin{array}{l}\text { Reading } \\
\text { understanding }\end{array}$ & (6-a) & & $(7 \underline{a})$ & \\
\hline D - 48 (Gen. Intel.) & $(7 \underline{a})$ & & (6ㅁ) & \\
\hline DAT - VR & & $3 \underline{a}$ & & \\
\hline \multicolumn{5}{|l|}{ DAT - NA } \\
\hline DAT - SR & & (5a) & & \\
\hline $\mathrm{DAT}-\mathrm{VR}+\mathrm{NA}$ & & (7aㅗ & & \\
\hline Factor A 16PF & & & & 5 \\
\hline Factor E 16 PF & (5a) & & $4 \underline{a}$ & $3 \underline{a}$ \\
\hline Factor C 16 PF & (8-a) & & & \\
\hline "Scientific" Kuder-C & $(4 \underline{a})$ & & & \\
\hline № variables chosen & 3 & 4 & 4 & 5 \\
\hline
\end{tabular}

The numbers in the Table indicate the order in which each one was introduced into the equation. Those in parenthesis indicate variables that could be rejected due to t heir low predictive value. 
TABLE IV

Some Values of Prediction Equations (Intermediate Exams Excluded as Independent Variable)

\begin{tabular}{|l|l|l|l|l|}
\hline Values & Criterion & & & \\
\hline & Mathematics & Physics & Chemistry & Biology \\
\hline Multiple R & 0.8023 & 0.7409 & 0.7409 & 0.7680 \\
\hline Shrunken R & 0.7822 & 0.7140 & 0.7196 & 0.7590 \\
\hline $\begin{array}{l}\text { Percentage of } \\
\text { explained } \\
\text { varian. (R2) }\end{array}$ & $61 \%$ & $51 \%$ & $52 \%$ & $58 \%$ \\
\hline Error* & 6.1 & 6.8 & 7.0 & 6.7 \\
\hline
\end{tabular}

* Scaled score points $(T=10 Z+50)$ TABLE V

TABLE V

Some Values of Prediction Equations Including Intermediate Exam Results as independent Variable

\begin{tabular}{|l|l|l|l|l|}
\hline Values & Criterion & & & \\
\hline & Mathematics & Physics & Chemistry & Biology \\
\hline $\begin{array}{l}\text { Multiple } \\
\text { (Shrunken) }\end{array}$ & 0.8805 & 0.8614 & 0.8412 & 0.8638 \\
\hline $\begin{array}{l}\text { Percentage of } \\
\text { explained } \\
\text { varian. (R2) }\end{array}$ & $77.5 \%$ & $74.2 \%$ & $70.1 \%$ & $74.6 \%$ \\
\hline Error & 4.5 & 4.8 & 5.4 & 5.0 \\
\hline
\end{tabular}

Prediction of Academic Achievement: Prediction Equations

Once the relations of the different variables had been studied, a calculation of prediction equations was made using the programme PAES 010. The prediction equations allow us to know what can be expected of each student as regards his academic achievement so as to be able to contrast what is expected with what in fact happens. The process for obtaining multiple regression equations is long and rather tiresome, especially if one wants to obtain the best possible equation from the available data. It is of the utmost importance to fix the correct order for entering the variables in the equation as this can increase or decrease the capacity of Prediction of each one in relation to the criterion, taking into account the overlapping and suppression that may occur in some variables because of the degree of association (Garret, 1966; Kerlinger, 1964).

Without entering into great detail, we may underline the following:

(a) The marks received in secondary school and the marks from the State entrance exam were included in first place in all the equations as they were the variables that showed the greatest predictive capacity. 
(b) The academic achievement tests were included in second, third and fourth place in the different equations which shows their importance in the prediction of achievement in university studies. In our opinion these tests act really in a complementary way to the previous marks as they were constructed to measure knowledge and intellectual capacities in the different subjects which had in fact been studied in some degree previously.

(c) Some of the differential aptitudes of intelligence such as verbal reasoning have shown a certain predictive value, although fess than those mentioned previously.

(d) It has been shown that personality, at any rate in mathematics, chemistry and biology has a moderate influence on the academic achievement of the students.

(e) Vocational interests have not been shown to influence the results and are therefore of little use as predictors.

Accepting with Bloom the importance of knowing with precision "cognitive entry behaviors," we established a hypothesis in which we suggested that a combination of factors related to knowledge and intellectual habits combined with differential aptitudes of intelligence would be the best predictors of academic achievement. At the same time we would be able to explain a large percentage of criterion variance. This was proven to a certain degree when we included the results of the first intermediate exam in the university as independent variables. The results of both cases are shown in Tables IV and V. These new variables have replaced the previous ones as the best predictors, probably because they represent better what the university teachers expect of their students. The variance percentages explained have risen considerably and the error has been reduced.

Summarizing the results of this second group of equations we can say that:

(a) We confirmed, once again, that previous academic results - this time the results of the first intermediate exam - are the best predictors of academic achievement.

(b) For this reason the differential aptitudes of intelligence and general intelligence improve the prediction considerably.

(c) The other variables are relegated to the last places in the equations when the estimations of the previous variables possess an adequate predictive value.

For these reasons we may conclude that a reliable and valid battery of achievement tests and a series of differential aptitude tests of intelligence are the best predictors of academic achievement.

Educational Implications of the Prediction

Some of the reasons for which we maintain that this prediction is an instrument of great use in university education are as follows: 
(1) They allow the teachers to know, prior to the beginning of the academic sessions, what may be expected of each student.

(2) The teachers may know what personality characteristics influence this appraisal and in what degree.

(3) They help to define priorities for helping those students for whom a deficient achievement may be expected.

(4) They will tell us what error there has been in our estimation. This knowledge allows the teachers to take advantage of this same error. For example, it is useful to tell the student what can be expected from him, stating the prediction plus the possible error. Obviously it is a question of not allowing the student to fall below the prediction minus the possible error.

(5) In education it is not only a question of merely knowing but also of finding out what the obstacles are that can hinder the process towards adequate academic achievement. Of course it is possible that some students have not really achieved a sufficient level to be in the university. But if they have already been accepted it is a question of helping them to achieve all they can.

(6) The counselling process in the university would be improved considerably if the teachers could count on precise information about each student at least in the aspects which most affect their academic achievement.

(7) Also it would be useful to determine the minimum value of each predictor. That is, the value which would assure a satisfactory achievement level. This would be easy to determine and could be of great use in an objective process of selection of students for the university in the future.

(8) One last aspect that should be mentioned about achievement prediction is the fact that it will help the teachers to demand of the students not only a sufficient level but also a satisfactory level.

In this way, comparing what is expected with what actually happens, we will know - and it is the only way to know - if the teaching-learning process is as efficient as it should be. This may influence the demands the teacher makes of himself and the demands he makes of the students.

New studies will be needed in this field. Perhaps the most urgent are those which can produce adequate batteries of achievement tests, because not only are they such good predictors, but also they give an initial diagnosis of the situation of each student as regards the subjects to be studied. This knowledge should be used from the beginning to give adequate information to the teachers and to the student. Any correctional action taken at the beginning of university studies will almost certainly be useful and will permit less failures. One should not forget that personalized attention - within logical limits - should not be absent from the university scene. 
Adams, G. S. (1970). Medición y evaluación en educación, psicología y guidance' Barcelona: Edit. Herder.

Aguirre, V. M. (1980). "Estudio longitudinal de las pruebas de admisión en una muestra de alumnos de la Facultad de Medicina". Tesis Doctoral, Facultad de Filosofía y Letras. Universidad de Navarra. Pamplona.

Angoff, N. H. (1971). "Scales, norms, and equivalent scores," in Thorndike, R. L., (ed.) Educational Measurement. Washington: American Council of Education.

Best, J. W. (1974). Cómo investigar en educación. Madrid: Edit. Morata.

Blai, B. Jr. (1980). "N on-intellective predictors of academic success," Scientia Pedagogica Experimentalis. XVII (2): 149-456.

Bloom, B. S., Engelhart, M. D., Furet, E. J., Hill, W. H. and Krathwohl, D. R. (1971). Taxonomía de los objetivos de la educación. Buenos Aires: Edit. Ateneo.

Bloom, B. S. (1975). "Mastery learning," in Block, J. H.: Cómo aprender para lograr el dominio de lo aprendido. Buenos Aires: Edit. Ateneo.

Bloom, B. S. (1980). "New directions in educational research: alterable variables" in Mesa Seminar., Dept. of Education. University of Chicago.

Castillo Ceballos, G. (1978). La dirección de un centro educativo y la metodología del trabajo intelectual. Tesis doctoral. Universidad de Navarra. Pamplona.

Cattell, R. B. (1971). Abilities their Structure, Growth and Action. Boston: Houghton Mifflin Co.

Cattell, R. B., Eber, H. W. and Tatsuoka, M. M. (1970). Handbook for the Sixteen Personality Factor-Questionarie. Campaing, IL: IPAT.

Cid Palacios, R. (1977). "Rasgos de madurez y éxito en las pruebas de acceso a la Universidad". Zaragoza. Instituto de Ciencias de la Educación.

Cronbach, L. J. (1954). Educational Psychology. New York: Harcourt, Brace and Company.

Cronbach, L. J. (1970). Essentials of Psychological Testing. New York: Harper and Row., Publishers.

Dumont, R. G. and Troelstrup, R. L. (1981). "Measures and predictors of educational growth with four years of college," Research in Higher Education 14 (1): 31-47.

Escudero Escorza, T. (1981). "Selectividad y rendimiento académico de los universitarios. Condicionantes psicológicos, sociológicos y educacionales". Zaragoza. Instituto de Ciencias de la Educación.

Feletti, G. I. and Fisher, L. A. (1979). "Evaluation of process and product in medical education." PLET. Vol. 16 (4). 
Ferguson, G. A. (1976). Statistical Analysis in Psychology and Education. New York: McGrawHill.

Ferrier, B. M. and Gauldie, J. (1979). "process for selection of medical students at McMaster University," PLET. Vol. 16 (4).

Froemel, J. and Leyton, F. (1980). "The effect of cognitive entry behaviors on school achievement," in Mesa Seminar. Dept. of Education. University of Chicago.

Garret, H. E. (1966). Estadística en Psicología y Educación. Buenos Aires:, Edit. Paidos.

Gonzalez-Simancas, J. L. (1973). Un modelo teórico de acción tutorial en la Universidad. Pamplona: EUNSA.

Guilford, J.P. (1965). Fundamental Statistics in Psychology and Education. New York: McGrawHill

Kerlinger, F. N. (1964). Foundations of Behavioral Research. New York: Holt. Rinehart and Winston.

Muraky, E. and Whaley, T. (1980). "Affective entry characteristics," in Mesa Seminar. Dept. of Education. University of Chicago.

Murphy, R. J. L. (1981). "Symposium: Examinations 0-level grades and teacher's estimates as predictors of the A-level results of U CCA applicants," British Journal of Educational Psychollogy 51:1-9

Noll, V.H. and Scannell, D. P. (1972). Introduction to Educational Measurement. Boston: Houghton Mifflin

Obrien, M.L. and Giinsburg, J. M. (1980). "Time on task and school achievement" in Mesa Seminar. Dept. of Education. University of Chicago.

Schneider, W., Haglund, A., Petterson, G. and Varde, E. (1971). "Interest: Integrated Retrieval and Statistics. A program package for information retrieval and statistical analyses," Uppsala University Data Center. IBM European Program Library Program No. 360D.

Seashore, H.G. (1968), "Methods of expressing test scores," in Gronlund, N. E. (ed.) Readings in Measurement and Evaluation. New York: MacMillan Company.

Seisdedos, N. (1978), 16 PF. Monografía técnica. Madrid, Tea Ediciones. S.A.

Thorndike, R.L. (1965). Measurement and Evaluation in Psychology and Education. New York: John Wiley and Sons

Thorndike, R.L. and Hagen, E. (1978). Tests y técnicas de medición en psicología y educación. México: Edit. Trillas.

Touron Figueroa, J. and Arrieta J. "La utilización del programa PAESOIO en el cálculo de ecuaciones de regresión múltiple con el método Wherry-Doolittle: su aplicación en la predicción del rendimiento académico. Revista Española de Pedagogía (in press). 
Ubieto Arteta, A. (1981). Técnicas básicas para el estudio. Zaragoza. Edit. Instituto de Ciencias de la Educación. Universidad de Zaragoza.

Zielke, W. (1973). Leer mejor y más rápido. Bilbao. Ediciones Deusto. 